\title{
SEWAGE SLUDGE MANAGEMENT IN A SEWAGE TREATMENT PLANT
}

\author{
Dariusz KRÓLIK ${ }^{1}$, Przemysław WYPYCH ${ }^{2}$, Jakub KOSTECKI \\ University of Zielona Góra, Zielona Góra, Poland
}

\begin{abstract}
Sewage sludge produced in municipal sewage treatment plants, because of its physicochemical and sanitary properties, is a serious threat to the environment. In order to neutralize it, various methods of processing are used, which directly affect the quantity and quality of produced sewage sludge, which in the final stage can be used naturally. Properly managed sludge management is presented on the example of a sewage treatment plant, conducting the methane fermentation process with the production of biogas.
\end{abstract}

Keywords: sewage sludge, biogas, sewage treatment plant

\section{INTRODUCTION}

The indispensability of conducting sludge management in sewage treatment plants is closely related to their operation. Sewage sludge is formed as a product in the sewage treatment process and then undergoes appropriate treatment mechanisms. In the final stage, it must be properly disposed of or managed [6, 9]. One of the basic and cheapest forms of sewage sludge management is its agricultural use, because it has soil-forming and fertilizing features. Before being used, it must not be characterized by odour nuisance, the presence of pathogenic organisms and the unacceptable content of heavy metals for this purpose.

\footnotetext{
${ }^{1}$ Corresponding author: University of Zielona Góra, Institute of Environmental Engineering, Z. Szafrana st 15, 65-516 Zielona Góra, Poland, e-mail: d.krolik@iis.uz.zgora.pl, tel. +48683282612

${ }^{2}$ Student of the University of Zielona Góra, Poland
} 
The legal act that regulates the possibility of agricultural use of sewage sludge for the aforementioned properties is the Regulation of the Minister of the Environment of 6 February 2015 on municipal sewage sludge (Journal of Laws of 2015 item 257) [2, 4, 6, 10].

Effective stabilization, hygienisation and drainage of sludge depend strictly on the direction of sewage sludge neutralization. The most popular way is to conduct anaerobic stabilization in closed fermentation chambers. In addition to decomposition of organic compounds, the reduction of odour nuisance and the inactivation of pathogenic organisms, a parameter that significantly affects the universality of this method, can be done by the production of high-energy biogas. Appropriate processing of fermentation gas allows to significantly cover the energy demand of sewage treatment plants $[1,3,6,7,8]$.

This article presents a process of treatment of sewage treatment plant sludge with methane fermentation along with the quantity and properties of primary, secondary, digestate and dehydrated sludge. The amount of biogas produced along with the amount of energy produced was also presented, which was used to prepare the energy balance. The properties of sludge classified in terms of the content of pathogenic organisms and heavy metals were also compared with the Regulation of the Minister of Environment of 6 February 2015 in order to determine the possibility of further use of sewage sludge in agriculture. Data refer to the period from 2015 to 2016 [10].

\section{SEWAGE SLUDGE TREATMENT PROCES}

Operation of sewage treatment plants includes clarification of municipal sewage in physical, chemical and biological processes. By adopting certain assumptions regarding the quantity and quality of raw sewage, a mechanical and biological treatment plant with increased biogen removal was selected and built. The sewage treatment process consists of a mechanical part consisting of elements such as grilles, an aerated sand trap with a grease trap and a longitudinal pre-settling tank as well as a biological part comprising a biological reactor and two secondary settling tanks. In addition to the sewage treatment process, there is also a sewage sludge treatment process. The scheme of sewage treatment and sewage sludge treatment is presented below (Fig.1).

After the processes of dephosphatation, nitrification and denitrification in the biological reactor (BR), part of the biological mass is sent back into the recirculation cycle and as the so-called recirculated sludge is subjected to mixing in the separation chamber before the biological reactor. The remaining amount of the biological mass is excluded from the process and as the so-called excess sludge is directed to further processing. Due to high hydration, excessive sludge is concentrated in mechanical sieve drums. Subsequently, it is mixed with the pre- 
settling sludge coming from the settling tank, in the gravity pre-concentrator, and the so-called leachate (sludge supernatant) is directed to the process water tank. Next, the thickened raw sludge is sent back to the closed fermentation chamber (CFC) to reduce the amount of organic matter, the level of pathogenic organisms and the ability to rot. During the anaerobic digestion process (about 20 days), the sludge is stabilized, and biogas is also released, which is used to generate heat and electricity.

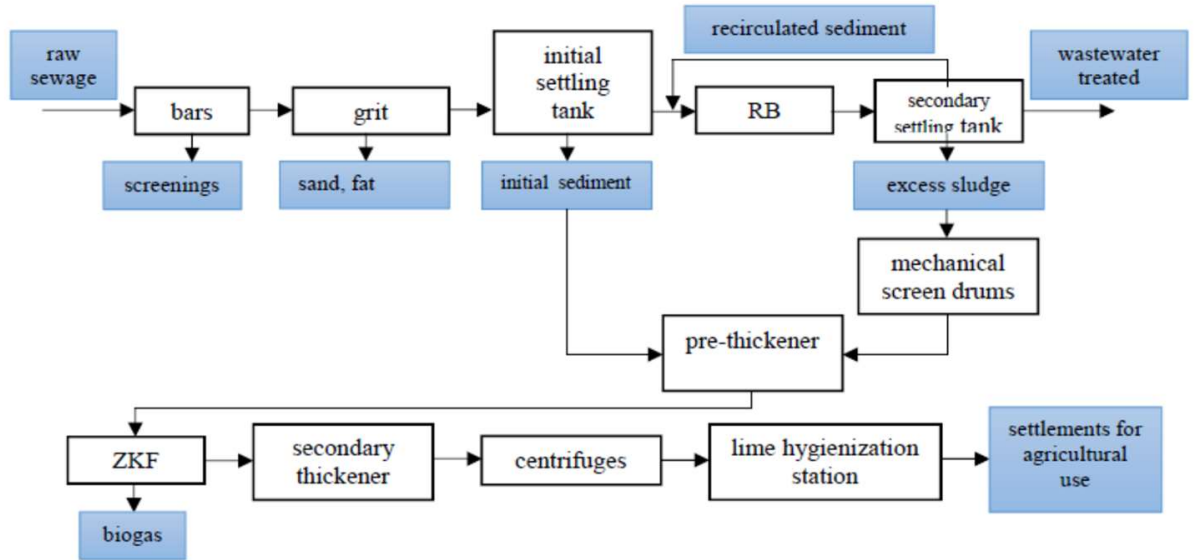

Fig. 1. A wastewater treatment sequence including treatment of sewage sludge

The fermented sewage sludge in the secondary gravity thickener is again compacted, and then dehydrated in two centrifuges. In the final section of the technological process of sludge processing, it is hygienized with highly reactive lime and directed to agricultural use.

\section{QUANTITATIVE AND QUALITATIVE BALANCE OF SEWAGE SLUDGE}

In sewage treatment plants, several types of sludge are formed with different properties after successive stages of sewage clarification, i.e. initial and excessive sludge, and during treatment and disposal of sewage, i.e. condensed excess sludge, fermented and dehydrated sludge. Their parameters are the percentage content of the organic part [\%], and the value of the dry residue, expressed in $\mathrm{kg} / \mathrm{m}^{3}$. Measurements were performed up to 3 times each month. The results of the quantity and quality of individual types of sewage sludge in 2015-2016 are presented in the tables below. 
Table 1. The amount and quality of initial sludge in 2015 and 2016 [5]

\begin{tabular}{|l|l|l|l|l|}
\hline Year & Quantity & $\begin{array}{l}\text { Average } \\
\text { (about) }\end{array}$ & $\begin{array}{l}\text { The range of } \\
\text { organic } \\
\text { content }\end{array}$ & $\begin{array}{l}\text { The range of } \\
\text { dry residue }\end{array}$ \\
\hline- & $\mathrm{m}^{3}$ & $\mathrm{~m}^{3} / \mathrm{d}$ & $\%$ & $\mathrm{~kg} / \mathrm{m}^{3}$ \\
\hline 2015 & 23334 & 64 & $69-80$ & $16-31$ \\
\hline 2016 & 20219 & 55 & $75-79$ & $11.3-26.4$ \\
\hline
\end{tabular}

In $2016,3115 \mathrm{~m}^{3}$ less initial sludge was created than in 2015 . The monthly range of sludge produced ranged from 1728 to $2794 \mathrm{~m}^{3}$ (2015) and from 1299 to $1970 \mathrm{~m}^{3}$ (2016).

Table 2. Quantitative parameters of excessive sludge before and after compaction

\begin{tabular}{|l|l|l|l|l|l|}
\cline { 2 - 5 } \multicolumn{1}{l|}{} & Excessive sludge & \multicolumn{2}{l|}{ Concentrated excess sludge } & \\
\hline Year & Quantity & $\begin{array}{l}\text { Average } \\
\text { (about) }\end{array}$ & Quantity & $\begin{array}{l}\text { Average } \\
\text { (about) }\end{array}$ & $\begin{array}{l}\text { The range } \\
\text { of monthly } \\
\text { volume } \\
\text { reduction }\end{array}$ \\
\hline- & $\mathrm{m}^{3}$ & $\mathrm{~m}^{3} / \mathrm{d}$ & $\mathrm{m}^{3}$ & $\mathrm{~m}^{3} / \mathrm{d}$ & $\%$ \\
\hline 2015 & 38335 & 105 & 12691 & 35 & $48-76$ \\
\hline 2016 & 49933 & 136 & 13906 & 38 & $55-80$ \\
\hline
\end{tabular}

Excessive sludge must be compacted in mechanical sieve drums due to the low dry matter content in order to mix it with the initial sludge. The results of sludge volume reduction before and after compaction are shown above.

In a sewage treatment plant, due to the presence of two secondary settling tanks, more excess sludge than initial sludge from one settler is produced. The monthly range of sludge produced ranged from 2000 to $5867 \mathrm{~m}^{3}$ (2015) and from 2023 to $6130 \mathrm{~m}^{3}$ (2016). For mechanically compacted sludge, these values oscillated successively from 837 to $1458 \mathrm{~m}^{3}$ (2015) and from 829 to $1744 \mathrm{~m}^{3}$ (2016).

In $2015,11598 \mathrm{~m}^{3}$ less excess sludge and $1215 \mathrm{~m}^{3}$ less of mechanically compressed sludge was formed less than a year later. Dry residue oscillated in the range from 28 to $35 \mathrm{~kg} / \mathrm{m}^{3}$ for excess sludge, and for compacted sludge from 33 to $48 \mathrm{~kg} / \mathrm{m}^{3}$ in 2015 . In 2016 , it was successively between $28-33 \mathrm{~kg} / \mathrm{m}^{3}$ and $31-54 \mathrm{~kg} / \mathrm{m}^{3}$. The range of the organic content in 2015 for excess sludge was 70 to $78 \%$, and for condensed one from 69 to $74 \%$. The following year, it was successively in the ranges of $76-78 \%$ and $74-77 \%$. The reduction process has little effect on the organic content percentage.

During the treatment of sludge, also fermented and dehydrated sludge is formed. After the anaerobic fermentation process, more specifically mesophilic fermentation, it is dehydrated with the effect of levelling the volume. The quantitative parameters are presented below. 
Table 3. Quantitative parameters of fermented and dehydrated sludge with volume reduction

\begin{tabular}{|l|l|l|l|l|l|}
\cline { 2 - 6 } \multicolumn{1}{c|}{} & Fermented sludge & \multicolumn{2}{l}{ Sludge is dehydrated } & \\
\hline Year & Quantity & $\begin{array}{l}\text { Average } \\
\text { (about) }\end{array}$ & Quantity & $\begin{array}{l}\text { Average } \\
\text { (about) }\end{array}$ & $\begin{array}{l}\text { The range of } \\
\text { monthly } \\
\text { volume } \\
\text { reduction }\end{array}$ \\
\hline- & $\mathrm{m}^{3}$ & $\mathrm{~m}^{3} / \mathrm{d}$ & $\mathrm{m}^{3}$ & $\mathrm{~m}^{3} / \mathrm{d}$ & $\%$ \\
\hline 2015 & 41254 & 113 & 2306 & 6 & $93-97$ \\
\hline 2016 & 39682 & 108 & 2769 & 8 & $91-95$ \\
\hline
\end{tabular}

The monthly range of fermented sludge produced ranged from 2727 to $3995 \mathrm{~m}^{3}$ (2015) and from 2516 to $3826 \mathrm{~m}^{3}$ (2016), and for the dehydrated - 131-239 $\mathrm{m}^{3}$ (2015) and 179-284 $\mathrm{m}^{3}$ (2016). The dry residue remained in the range from 16.7 to $18.5 \mathrm{~kg} / \mathrm{m}^{3}$ (2015) and from 16.8 to $19.4 \mathrm{~kg} / \mathrm{m}^{3}$ (2016) for fermented sludge, and for dehydrated from $190226 \mathrm{~kg} / \mathrm{m}^{3}$ (2015) and from 183 to $211 \mathrm{~kg} / \mathrm{m}^{3}$ (2016).

The value of dry residue in a given period for dehydrated sludge was from 10 to even 13 times higher than for fermented sludge. The process of treatment of sludge in the sewage treatment plant allows effective reduction of volume and hydration, while increasing the dry matter.

\section{ENERGETIC EFFICIENCY}

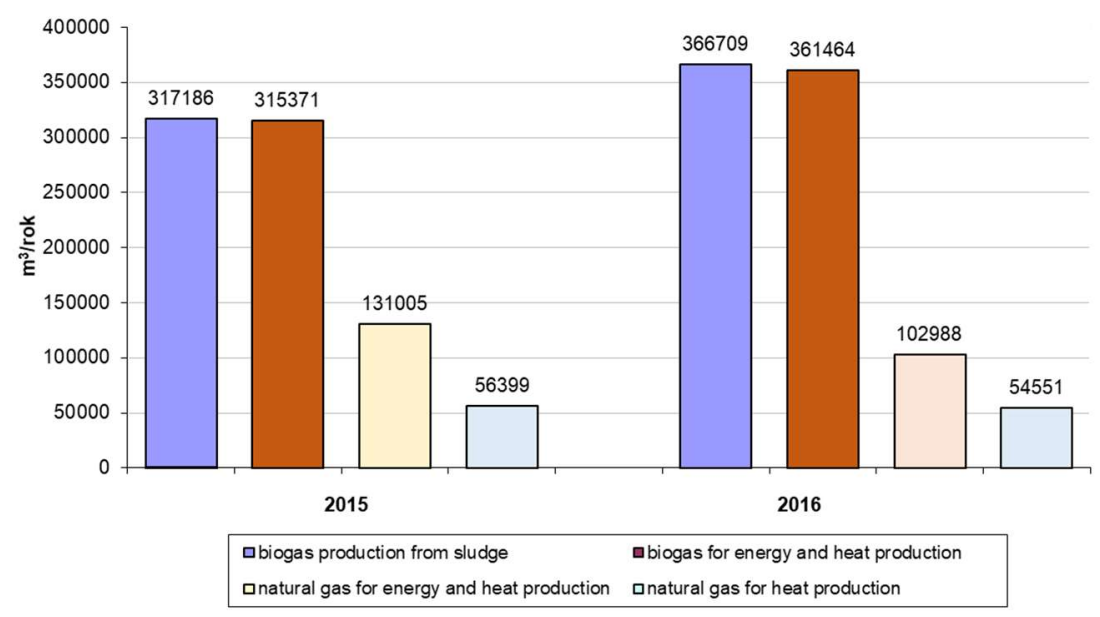

Fig. 2. The amount of biogas and natural gas [5] 
During the process of anaerobic stabilization of sewage sludge taking place in a closed fermentation chamber, biogas is released. The receivers of the produced biogas are two combustion engines with a capacity of $230 \mathrm{~kW}$ (also using natural gas) and $220 \mathrm{~kW}$, a central heating boiler and a torch for burning excess gas. In 2015, $317186 \mathrm{~m}^{3}$ was produced, and in 2016, in turn, $366709 \mathrm{~m}^{3}$ of biogas from fermenting sludge. The average amount of biogas produced in a given period was, in turn, approx. $869 \mathrm{~m}^{3} / \mathrm{d}$ and around $1002 \mathrm{~m}^{3} / \mathrm{d}$. The figure below shows the amount of biogas and natural gas used in generating energy and heat.

In $2015,1815 \mathrm{~m}^{3}$ of biogas was burnt in the torch and $5245 \mathrm{~m}^{3}$ in 2016 . From the burnt biogas and natural gas, $1089568 \mathrm{kWh}(2015)$ and $1112036 \mathrm{kWh}(2016)$ of electricity and heat were produced respectively. These quantities have an impact on the energy balance of the sewage treatment plant (Figure 3). Energy self-sufficiency based on own production and purchased energy in relation to total electricity consumption, amounted to approx. 59\% in 2015 and approx. $67 \%$ in 2016.

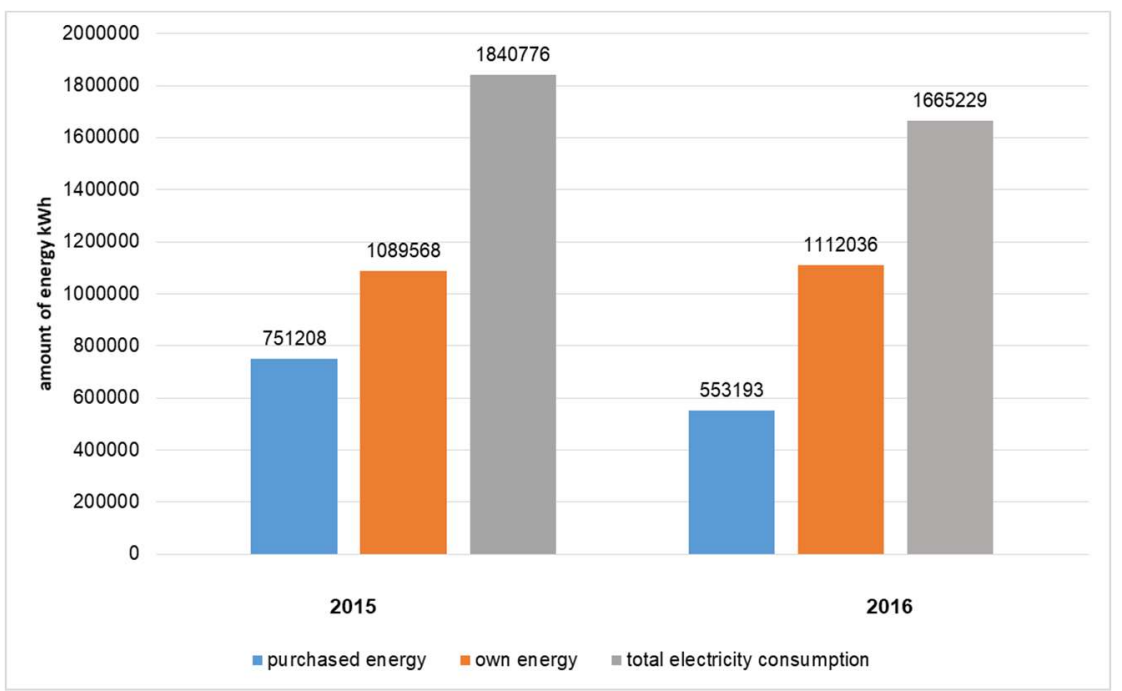

Fig. 3. Energy balance of sewage treatment plant in 2015-2016 [5]

\section{THE FINAL MANAGEMENT OF SEWAGE SLUDGE}

Sewage sludge, after the densification step, anaerobic stabilization and dehydration, is subjected in the final stage of hygienization with high-reactive lime. Through the use of this process, pathogenic organisms contained in sludge are destroyed. To be used for agricultural purposes, the produced sediments must be subjected to quality tests and therefore, their samples are subjected to analysis 
in accredited laboratories. Tests in terms of physico-chemical properties and the presence of pathogenic organisms are carried out. The most important, however, are those concerning the content of heavy metals, the presence of pathogenic bacteria from the Salmonella genus and the number of living eggs of intestinal parasites Ascaris sp., Trichuris sp. and Toxocara sp. Their acceptable contents in sewage sludge for agricultural use are regulated by law and included in the Regulation of the Minister of the Environment of 6 February 2015 (Journal of Laws of 2015 item 257) on municipal sewage sludge. Quality tests were carried out once every 4 months. Their results relate to the period 2015-2016 and are presented below together with the admissible value.

Table 4. The results of measurements of heavy metals content in stagnant sediments [11]

\begin{tabular}{|l|l|l|l|l|l|l|l|l|}
\hline $\begin{array}{l}\text { Determined } \\
\text { heavy metal }\end{array}$ & Unit & $\begin{array}{l}23.02 . \\
2015\end{array}$ & $\begin{array}{l}21.07 . \\
2015\end{array}$ & $\begin{array}{l}03.12 . \\
2016\end{array}$ & $\begin{array}{l}31.03 . \\
2016\end{array}$ & $\begin{array}{l}10.08 . \\
2016\end{array}$ & $\begin{array}{l}23.02 . \\
2015\end{array}$ & $\begin{array}{l}\text { Permissible } \\
\text { content }\end{array}$ \\
\hline Cadmium & $\begin{array}{l}\mathrm{mg} / \mathrm{kg} \\
\text { d.m. }\end{array}$ & 7.07 & 1.18 & 1.5 & 1.07 & 1.28 & 1.09 & 20 \\
\hline Copper & $\begin{array}{l}\mathrm{mg} / \mathrm{kg} \\
\text { d.m. }\end{array}$ & 66.6 & 376 & 375 & 276 & 365 & 374 & 1000 \\
\hline Nickel & $\begin{array}{l}\mathrm{mg} / \mathrm{kg} \\
\mathrm{d} . \mathrm{m} .\end{array}$ & 14.2 & 24 & 19.8 & 21.6 & 17.6 & 22.5 & 300 \\
\hline Lead & $\begin{array}{l}\mathrm{mg} / \mathrm{kg} \\
\mathrm{d} . \mathrm{m} .\end{array}$ & 32.1 & 46.3 & 36.5 & 34.1 & 48.7 & 38.4 & 750 \\
\hline Zinc & $\begin{array}{l}\mathrm{mg} / \mathrm{kg} \\
\mathrm{d} . \mathrm{m} .\end{array}$ & 595 & 1257 & 1241 & 1010 & 1320 & 1160 & 2500 \\
\hline Mercury & $\begin{array}{l}\mathrm{mg} / \mathrm{kg} \\
\mathrm{d} . \mathrm{m} .\end{array}$ & $<0.05$ & 0.93 & 0.77 & 0.65 & 0.68 & 2.05 & 16 \\
\hline Chrome & $\begin{array}{l}\mathrm{mg} / \mathrm{kg} \\
\mathrm{d} . \mathrm{m} .\end{array}$ & 14.7 & 28.3 & 26.6 & 23.7 & 20.4 & 23.5 & 500 \\
\hline
\end{tabular}

Salmonella bacteria were not isolated in the tested samples, and the total number of live intestinal parasitic eggs Ascaris $s p$., Trichuris $s p$., Toxocara $s p$. in $1 \mathrm{~kg}$ of dry matter amounted to 0 . The results of measurements of other physicochemical parameters of sewage sludge are presented below.

Table 5. Results of other physicochemical measurements [11]

\begin{tabular}{|l|l|l|l|l|l|l|l|}
\hline Marked parameter & Unit & $\begin{array}{l}23.02 . \\
2015\end{array}$ & $\begin{array}{l}21.07 . \\
2015\end{array}$ & $\begin{array}{l}\text { 03.12. } \\
2016\end{array}$ & $\begin{array}{l}31.03 . \\
2016\end{array}$ & $\begin{array}{l}10.08 . \\
2016\end{array}$ & $\begin{array}{l}23.02 . \\
2015\end{array}$ \\
\hline $\mathrm{pH}$ & - & 8.4 & 11.8 & 8 & 8 & 7.6 & 7.9 \\
\hline dry weight & \% d.m. & 15.9 & 19.7 & 16.9 & 20.3 & 14.7 & 12.8 \\
\hline organic substance & \% d.m. & 72.4 & 66.2 & 68.5 & 73 & 66.3 & 65.6 \\
\hline $\begin{array}{l}\text { general } \\
\text { phosphorus }\end{array}$ & \% d.m. & 2.59 & 2.61 & 2.55 & 1.65 & 2.41 & 2.51 \\
\hline
\end{tabular}




\begin{tabular}{|l|l|l|l|l|l|l|l|}
\hline calcium & \% d.m. & 1.82 & 3.66 & 3.15 & 2.35 & 3.11 & 3.1 \\
\hline magnesium & \% d.m. & 0.59 & 0.5 & 0.51 & 0.4 & 0.57 & 0.66 \\
\hline $\begin{array}{l}\text { content of } \\
\text { ammonium } \\
\text { nitrogen }\end{array}$ & $\%$ d.m & 0.59 & 0.61 & 0.56 & 0.8 & 0.4 & 0.7 \\
\hline $\begin{array}{l}\text { total nitrogen } \\
\text { content }\end{array}$ & \% d.m. & 5.32 & 5.3 & 4.92 & 5.62 & 4.65 & 5.23 \\
\hline
\end{tabular}

Based on the results of the research, it was found that sewage sludge produced in the sewage treatment plant is safe in terms of physicochemistry and sanitation for use in agriculture, as well as for land reclamation. Sludge is not stored in any way, it occurs in the form of earth and is managed in the area of nearby villages.

\section{FINAL CONCLUSIONS}

Sludge treatment processes in sewage treatment plants reduce its mass and volume while increasing the dry matter content as well as reduce the amount of pathogenic organisms and the ability to emit odours.

The amount of biogas and natural gas produced in 2015 allowed for covering the level of total energy demand of the treatment plant at the level of $59 \%$, and in 2016 at the level of $67 \%$.

The analysis of the results of the physicochemical and sanitary parameters, in particular the content of heavy metals and pathogenic organisms in the sewage sludge, allowed to determine their compliance with the admissible values contained in the Regulation of the Minister of Environment of 6 February 2015 (Journal of Laws of 2015, item 257) in terms of the use of municipal sewage sludge in agriculture.

\section{REFERENCES}

1. Bauza-Kaszewska, J, Paluszak, Z and Skowron K 2010. Impact of sewage sludge compositing on the number of selected groups of indigenous microorganisms (Wptyw kompostowania osadów ściekowych na liczebność wybranych grup drobnoustrojów autochtonicznych). Woda-ŚrodowiskoObszary Wiejskie, 10, 19-27.

2. Bień, JB 2007. Sewage sludge - theory and practice (Osady ściekowe - teoria $i$ praktyka). Wydanie drugie poprawione i uzupełnione, Wydawnictwo Politechniki Częstochowskiej, Częstochowa.

3. Breza-Boruta, B 2012. Emission of microorganisms by a municipal waste landfill as a health risk factor (Emisja drobnoustrojów przez składowisko odpadów komunalnych jako czynnik zagrożenia zdrowotnego). Proceedings of ECOpole 2012, 6(2), 617-623. 
4. Butarewicz, A and Wiater, J 2014. Ways of using sludge from the Wastewater Treatment Plant in Bialystok (Sposoby wykorzystania osadów z Oczyszczalni Ścieków w Białymstoku). Inżynieria i Ochrona Środowiska, 17, nr 2, 281-291.

5. Operating data of sewage treatment plants 2015-2016 (Dane eksploatacyjne oczyszczalni ścieków 2015-2016).

6. Dębowski, M and Zieliński, M 2011. Sludge management of sewage treatment plants - identification of selected problems and proposed solutions (Gospodarka osadowa oczyszczalni ścieków - identyfikacja wybranych problemów i propozycje rozwiazań). Wydawnictwo VERLAG DASHOFER Sp. z o. o., Warszawa.

7. Krupa, K 2015. Sustainable biogas energy in sewage treatment plants (Zrównoważona energetyka biogazowa w oczyszczalniach ścieków). Polityka Energetyczna - Energy Policy Journal, 18, zeszyt 4, 101-112.

8. Kulikowska, D and Moszczyńska, M 2015. Sludge composting - process characteristics and compost quality analysis (Kompostowanie osadów ściekowych - charakterystyka procesu oraz analiza jakości kompostu). Gaz, Woda i Technika Sanitarna, 11, 36-39.

9. Rosik-Dulewska, C, Karwaczyñska, U and Głowala, K 2005. Variability of forms of occurrence of heavy metals in sewage sludge depending on their treatment technology (Zmienność form występowania metali ciężkich $w$ osadach ściekowych $w$ zależności od technologii ich przeróbki). Zeszyty Naukowe Wydziału Budownictwa i Inżynierii Środowiska Politechniki Koszalińskiej, Koszalin, seria: Inżynieria Środowiska, 22, 117-129.

10. Ordinance of the Minister of the Environment of February 6, 2015 on municipal sewage sludge (Rozporzadzenie Ministra Środowiska z dnia 6 lutego 2015 r. w sprawie komunalnych osadów ściekowych (Dz. U. 2015 poz. 257)).

11. Laboratory test results for hygrised sludge directed to natural use, 2015-2016 (Wyniki badań laboratoryjnych dla osadów zhigienizowanych kierowanych do wykorzystania przyrodniczego, 2015-2016).

Editor received the manuscript: 09.01.2019 